\title{
Pengaruh Kinerja Keuangan, Struktur.Modal, Profitabilitas, Kebijakan Hutang dan Kebijakan Dividen Terhadap Nilai Perusahaan Pada Perusahaan Yang Terdaftar di Bursa Efek Indonesia
}

\author{
Christania Sutanto', Mas Intan Purba², Venny Gunawan ${ }^{3}$, Jesslyn $^{4}$, Angel Lica5 \\ 1,2,3,4,5 Universitas Prima Indonesia \\ e-mail: ${ }^{2}$ masintanpurba84@gmail.com

\begin{tabular}{ccc}
\hline Diterima & Direvisi & Disetujui \\
$13-07-2021$ & $15-09-2021$ & $26-09-2021$ \\
\hline
\end{tabular}

\begin{abstract}
Abstrak - Perusahaan ladalah lorganisasi lyang ldibentuk lindividu latau lkelompok lyang lmenjual lbarang latau ljasa lpada lpembeli luntuk lmemperoleh 1laba. IPerusahaan lyang ltercatat ldi IBEI lyaitu lperusahaan lyang lterbuka luntuk lumum. IDengan lkata llain, lsaham lperusahaan ldapat ldimiliki latau ldibeli loleh lpublik. IPada ldasarnya lperusahaan ldengan lpotensi lmodal lyang lbesar lakan Imudah luntuk Imendaftar. IKinerja lkeuangan lsuatu lperusahaan lmerupakan lfaktor ldasar lperhitungan lbagi linvestor luntuk lmengambil lkeputusan linvestasi. lyang lmenjadi lpertimbangan lcalon linvestor ldalam lmemilih linvestasi. IPenelitian lini lmempunyai lcapaian lagar ldiketahui lserta ldilakukannya lanalisis IPengaruh IROA, IDER, INPM, IDAR, lserta IDPR lpada IPBV 1Ratio ldi lperusahaan.manufaktur libagian liindustri libarang likonsumsi liyang litercatat lidi liBEI litahun 120162019. IPendekatan lipenelitian liyang ldipakai liyaituipendekatan lkuantitatif lserta lmenggunakan lteknik lpengambilan lisampel lipurposive lisampling, 126 lisampel liperusahaan limanufaktur libagian liindustri libarang likonsumsi lyang litercatat lidi liBEI litahun li2016-2019. IJenis lidata liyang lidipakai lipada liyaitu lidata lisekunder. liData lisekunder lyaitu llaporan likeuangan liperusahaan limanufaktur libagian liindustri libarang likonsumsi liyang litercatat lidi liBEI litahun 12016-2019 lipada liweb lwww.idx.co.id. IHasilnya liROA, IDER, INPM, IDAR, lserta IDPR lmemiliki lipengaruh lisecara lsimultan lpada liPBV liRatio lidi liperusahaan limanufaktur libagian liindustri libarang likonsumsi liyang litercatat lidi liBEI ltahun li2016-2019. liSecara liparsial liROA, liNPM, liDAR limemiliki lipengaruh liserta lisignifikan lipada liPBV liRatio lidi lperusahaan.manufaktur libagian liindustri libarang likonsumsi liyang litercatat lidi liBEI litahun li2016 li- li2019. liSecara lparsial liDER ldan IDPR litidak liberpengaruh lisignifikan lipada liPBV IRatio lidi liperusahaan limanufaktur libagian lindustri lbarang likonsumsi liyang litercatat lidi liBEI litahun li2016-2019.).
\end{abstract}

Kata Kunci: ROA, DER, NPM, DAR, DPR dan PBV Ratio

Abstract - Pepper companies are organizations that are formed by individuals or groups that sell goods or services to buyers to earn profits. l Companies that are listed on IBEI are companies that are open to the public. In other words, the company's shares may be owned or purchased by the public. lBasically, a company with a large capital potential will make it easier to register. lThe financial performance of an lcompany is a basic factor for calculating linvestors to make investment decisions. which can be considered by potential investors in choosing an investment. $l l$ line research $l$ has $l$ the results of the match $l$ is known and $l$ analysis is carried out $l$ the Influence of IROA, IDER, INPM, IDAR, and IDPR $l$ on IPBV lRatio $l$ in l company. $l$ The research approach used is a quantitative approach and also uses the technique for taking lipurposive lisampling, 126 samples from five manufacturing companies in the Liang Lintang Liang Liang consumption Liang Liang Liang Liang Liang Sampling LiIng years LiBEI year 2016-2019. I The type of lidata that is used is lipada li, namely lysecondary lidata. liSecondary liSecondary data, namely lFinancial reports of five companies, manufacturing, Li-Industry, Libarang LiConsuming, Liyang,Record LiBEI, for the year 12016-2019, on the liweb lwww.idx.co.id. lThe result is that liROA, IDER, INPM, IDAR, and IDPR l have a simultaneous influence on liPBV liRatio of sticks in five manufacturing companies lipart of liyang liyang liyang consumption liyang li2016-2019 lyear. liLiparally, liROA, liNPM, liDAR li have a significant lys- sificant influence on liPBV liRatio lcompanies.manufacturing li-industrial libarang liyang liyang liyang liyang liyang liyang record liI- li2016 li- li2019. liPartially liDER l and IDPR did not have a significant effect on liPBV lThe ratio of lidi li of five companies manufacturing lise of lindustrial liconsump liyang liyang liyang liIl liI liy years 2016-2019.).

Keywords: ROA, DER, NPM, DAR, DPR and PBV Ratio 


\section{PENDAHULUAN}

Perusahaan adalah organisasi yang dibentuk oleh individu atau kelompok yang menjual barang atau jasa kepada pembeli dalam memperoleh laba. Perusahaan yang tercatat di BEI yaitu perusahaan yang terbuka untuk umum. Dengan kata lain, saham perusahaan dapat dimiliki atau dibeli oleh publik. Pada dasarnya perusahaan dengan potensi modal yang besar akan mudah untuk mendaftar. Kinerja keuangan suatu perusahaan merupakan capaian perusahaan dalam bentuk laporan yang menjadi dasar investor untuk mengambil keputusan investasi (Nisa \& Kurniasari, 2017). Untuk perusahaan, menjaga serta memperbaiki kinerja keuangan adalah syarat utama untuk menjaga permintaan investor. Laporan keuangan yang dikeluarkan perusahaan menggambarkan keadaan situasi keuangan perusahaan. Kinerja keuangan dapat diukur dengan profitabilitas perusahaan.

Nilai Perusahaan mendapatkan dampak dari banyak faktor, contohnya struktur modal. Struktur modal yaitu hasil banding dari hutang jangka panjang dengan ekuitas yang dinyatakan dengan DER (Maytariana \& Kertahadi, 2013). Struktur modal berhubungan dengan pengeluaran berkepanjangan perusahaan dan dihitung dengan rasio hutang berkepanjangan terhadap ekuitas (Sudana, 2011). Susunan modal penting untuk perusahaan sebab berkaitan dengan risiko dan tingkat keuntungan yang diharapkan dari pemegang saham (shareholder) serta memiliki pengaruh yang signifikan terhadapnya (Brigham \& Houston, 2011).

Nilai perusahaan mendapatkan dampak dari profitabilitas. Profitabilitas yaitu rasio untuk mengukur potensi perusahaan untuk mendapatkan laba di level penjualan, asset serta modal suatu saham (Hanafi \& Halim, 2012). Makin besar nilai keuntungan perusahaan, makin besar juga peluang menarik investor.

Selain itu, regulasi hutang juga berkaitan dengan value perusahaan. Regulasi ini adalah regulasi perusahaan perihal sejauh mana perusahaan tersebut menggunakan pembiayaan hutang. Hutang usaha yaitu alat yang sangat sensitif pada perubahan value perusahaan. Makin besar rasio hutang yang dipilih perusahaan di level tertentu, makin besar pula nilai perusahaan tersebut, jika keadaan dibalik maka nilai perusahaan akan semakin menurun.

Tujuan utama investor adalah meningkatkan kesejahteraan dengan harapan melalui imbal hasil berupa dividen ataupun capital gains. Disaat yang sama, perusahaan mengharapkan pertumbuhan yang berkelanjutan dalam mempertahankan kelangsungan perusahaan dan mensajikan kesejahteraan bagi pemegang saham. Kebijakan dividen mengacu pada kesatuan peraturan yang disetujui perusahaan pada proses penentuan banyaknya laba yang dapat dianggarkan untuk pemegang saham (Mohanasundari \& Vidhya, 2016). Ada relasi positif serta signifikan dari regulasi dividen dengan value perusahaan (Murekefu \& Ouma, 2012).

Tujuan utama perusahaan yaitu keberhasilan, dan tolak ukur suatu keberhasilan adalah nilai perusahaan. Nilai perusahaan mempunyai nilai penting di mata investor karena melalui nilai tersebut investor dapat mencapai suatu kepercayaan untuk melakukan investasi. Makin besar nilai perusahaan, makin kecil risiko yang diambil investor. Namun kenyataannya terdapat beberapa masalah yang terjadi di perusahaan manufaktur, terdapat di Tabel 1.1

Tabel 1.1

Fenomena Penelitian (Rupiah)

\begin{tabular}{|l|l|l|l|l}
\hline $\begin{array}{l}\text { N } \\
\text { O }\end{array}$ & $\begin{array}{l}\text { Kode } \\
\text { Emiten }\end{array}$ & $\begin{array}{l}\text { Tahu } \\
\mathrm{n}\end{array}$ & Total Ekuitas & Laba Bersih \\
\hline 1 & ICBP & 2016 & 18.500 .800 .000 .000 & 3.631 .300 .000 .000 \\
\hline & & 2017 & 20.324 .300 .000 .000 & 3.543 .200 .000 .000 \\
\hline & & 2018 & 22.707 .200 .000 .000 & 4.658 .800 .000 .000 \\
\hline & & 2019 & 26.671 .100 .000 .000 & 5.360 .000 .000 .000 \\
\hline 2 & ROTI & 2016 & 1.443 .000 .000 .000 & 280.000 .000 .000 \\
\hline & & 2017 & 2.820 .000 .000 .000 & 135.000 .000 .000 \\
\hline & & 2018 & 2.917 .000 .000 .000 & 127.000 .000 .000 \\
\hline & & 2019 & 3.093 .000 .000 .000 & 237.000 .000 .000 \\
\hline 3 & INDF & 2016 & 43.941 .400 .000 .000 & 5.266 .900 .000 .000 \\
\hline & & 2017 & 47.102 .800 .000 .000 & 5.097 .300 .000 .000 \\
\hline & & 2018 & 49.916 .800 .000 .000 & 4.961 .900 .000 .000 \\
\hline & & 2019 & 54.202 .500 .000 .000 & 5.902 .700 .000 .000 \\
\hline
\end{tabular}




\begin{tabular}{|l|l|l|}
\hline Total Hutang & $\begin{array}{l}\text { Deviden } \\
\text { Per Share }\end{array}$ & $\begin{array}{l}\text { Harga } \\
\text { Saham }\end{array}$ \\
\hline 10.401 .100 .000 .000 & 15.400 & 8.575 \\
\hline 11.295 .200 .000 .000 & 16.200 & 8.900 \\
\hline 11.660 .000 .000 .000 & 13.700 & 10.450 \\
\hline 12.038 .200 .000 .000 & 21.500 & 11.150 \\
\hline 1.477 .000 .000 .000 & 1.373 & 1.600 \\
\hline 1.739 .000 .000 .000 & 582 & 1.275 \\
\hline 1.477 .000 .000 .000 & 978 & 1.200 \\
\hline 1.589 .000 .000 .000 & 2.573 & 1.300 \\
\hline 38.233 .100 .000 .000 & 23.500 & 7.925 \\
\hline 41.298 .100 .000 .000 & 23.700 & 7.625 \\
\hline 46.621 .000 .000 .000 & 17.100 & 7.450 \\
\hline 41.996 .100 .000 .000 & 27.800 & 7.925 \\
\hline
\end{tabular}

Pada Tabel 1.1 dapat dijelaskan data diatas mengalami fluktuasi. Pada PT. Indofood CBP Sukses Makmur, Tbk tahun 2017 Total Ekuitas sebesar Rp 20.324.300.000.000 mengalami peningkatan dibandingkan tahun 2016 dengan Total Ekuitas sebesar Rp 18.500.800.000.000 dan harga saham tahun 2017 sebesar Rp 8.900 juga mengalami peningkatan dibandingkan tahun 2016 sebesar Rp 8.575 . dan PT. Nippon Indosari Corpindo, Tbk di tahun 2018 Laba Bersih sebesar Rp 127.000.000.000 mengalami penurunan dibanding tahun 2017 sebesar Rp 135.000.000.000 dan harga saham di tahun 2018 sebesar Rp 1.200 juga mengalami Penurunan dibandingkan tahun 2017 sebesar Rp 1.275 . Pada PT. Indofood Sukses Makmur tahun 2019 Total Hutang sebesar Rp 41.996.100.000.000 mengalami penurunan dibanding dengan tahun 2018 sebesar $\mathrm{Rp}$ 46.621.000.000.000 tetapi harga saham tahun 2019 sebesar Rp 7.925 mengalami peningkatan dibanding tahun 2018 sebesar Rp 7.450. Untuk Dividen Per share pada tahun 2017 sebesar Rp. 23.700 mengalami peningkatan dibandingkan tahun 2016 sebesar Rp 23.500.

\section{Teori Pengaruh Kinerja Keuangan terhadap Nilai Perusahaan}

Menurut (Fahrizal, 2013), Sebuah perusahaan yang mempunyai prospek yang baik dapat dinilai dengan mengamati nilai perusahaan dan kinerja perusahaan yang baik akan menerima respon positif dari investor dengan ditunjukkan dengan meningkatnya permintaan saham.

Menurut (Sartono, 2014), ROA mampu melakukan pengukuran potensi perusahaan guna mendapatkan keuntungan dari aset. Apabila nilai ROA makin tinggi, keuntungan perusahaan semakin besar. Menurut (Mariani \& Suryani, 2018), menyatakan laba perusahaan punya pengaruh positif yang signifikan pada nilai perusahaan.

\section{Teori Pengaruh Struktur Modal terhadap Nilai Perusahaan}

Menurut (Irham, 2011), struktur modal artinya rasio hutang yang termasuk hutang dalam waktu singkat serta berkepanjangan dengan ekuitas untuk memenuhi kebutuhan operasional perusahaan.

Menurut (Brigham \& Houston, 2011), bahwa para investor menginginkan perusahaan dengan keuntungan yang menjanjikan, sehingga investor tidak akan menjual saham serta menentukan untuk menambah dana baru melalui hutang.

Menurut (Sudana, 2011), menyatakan struktur modal merupakan perbandingan antara hutang jangka panjang dan modal sendiri.

\section{Teori Pengaruh Profitabilitas terhadap Nilai} Perusahaan

Menurut (Handayani, 2012) ROA mempunyai pengaruh positif signifikan pada perubahan keuntungan. Profitabilitas yaitu potensi perusahaan untuk menghasilkan atau mendapatkan keuntungan. Keuntungan perusahaan asalnya dari investasi serta penjualan perusahaan.

Menurut (Lestari \& Paryanti, 2016), makin besar keuntungan yang dimiliki, makin baik kinerja perusahaan.

Menurut (Wijaya, 2010), apabila profitabilitas tersebut tinggi akan menjadi kesempatan bagi perusahaan dalam mengendali aktivitas investasi yang akan dipengaruhi oleh skala profitabilitas perusahaan.

\section{Teori Pengaruh Kebijakan Hutang terhadap Nilai Perusahaan}

Menurut (Brigham \& Houston, 2011), menyatakan kebijakan hutang yaitu suatu kebijakan mengenai putusan perusahaan ketika beroperasi memakai financial leverage atau hutang keuangan.

Menurut (Ramadhan \& Marlina, 2016), kebijakan hutang mempunyai pengaruh negatif pada nilai perusahaan. Sebab perusahaan memiliki hutamg yang sangat besar dan resiko yang dihadapi perusahaan yang tinggi.

Menurut (Dwi \& Sudarwanto, 2014), apabila tingkat hutang lebih dari rasio hutang yang disahkan perusahaan, akan mengalami penurunan nilai perusahaan.

\section{Teori Pengaruh Kebijakan Dividen terhadap Nilai Perusahaan}

Menurut (Sofyaningsih \& Hardiningsih, 2011) kebijakan dividen berhubungan dengan kebijakan perusahaan tentang besarnya keuntungan yang dialokasikan pada pemegang saham.

Menurut (Wijaya, 2010), menyatakan kebijakan 
dividen memiliki pengaruh positif pada nilai perusahaan. Perusahaan yang mampu memberikan dividen besar akan memperoleh rasa percaya yang besar dari investor, sebab investor lebih memilih untuk menentukan tingkat returns investasi serta mengantisipasi resiko yang tidak pasti dari perusahaan.

Menurut (Palupi \& Hendiarto, 2018), apabila dividen yang dibagikan bernilai tinggi, perusahaan akan dianggap memiliki potensi keuntungan yang bagus dan sebaliknya. Jika rendah akan dianggap tidak menguntungkan sehingga taraf pembayaran dividen dapat meningkatkan nilai perusahaan.

\section{Kerangka Konseptual}

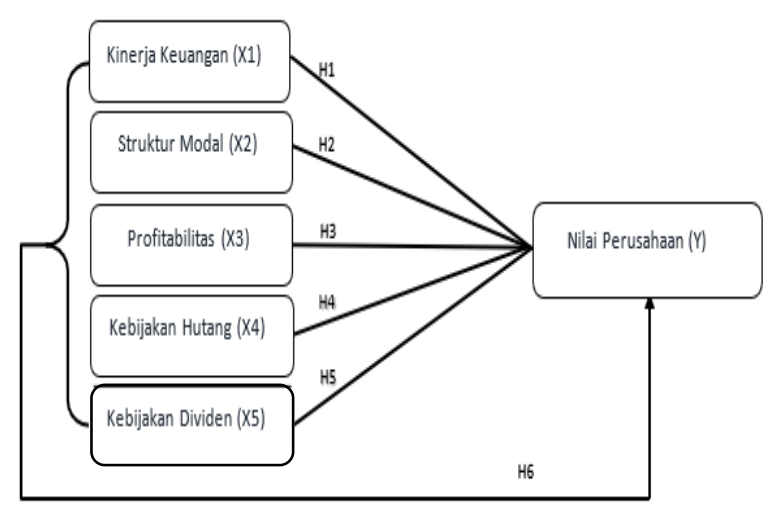

\section{Hipotesis Penelitian}

Didasarkan Kerangka Konseptual, hipotesis yang dikembangkan pada penelitian ini antara lain:

a. H1 : Kinerja Keuangan mempunyai dampak secara parsial dalam Nilai Perusahaan.

b. H2 : Struktur Modal mempunyai dampak secara parsial dalam Nilai Perusahaan.

c. H3 : Profitabilitas mempunyai dampak secara parsial dalam Nilai Perusahaan.

d. H4 : Kebijakan Hutang mempunyai dampak secara parsial dalam Nilai Perusahaan.

e. H5 : Kebijakan Dividen mempunyai dampak secara parsial dalam Nilai Perusahaan.

H6 : Kinerja Keuangan, Struktur Modal, Profitabilitas, Kebijakan Hutang, dan Kebijakan Dividen mempunyai dampak secara simultan dalam Nilai Perusahaann.

\section{METODE PENELITIAN}

Analisis kuantitatif adalah metode yang digunakan, sebab catatan atas kumpulan fakta atau biasa disebut data yang digunakan berbentuk digital. Variabel penelitian ditentukan dalam satuan yang bisa dihitung serta diukur. Metode analisis ini menggunakan perangkat lunak SPSS untuk menganalisis hasil pengujian komputasi yang dilakukan, seperti pengujian hipotesis klasik dan regresi linier berganda.

\section{Pendekatan Penelitian}

(Sugiyono, 2017) menyatakan penelitian kuantitatif adalah jenis penelitian yang mampu dijelaskan menjadi metode penelitian yang didasarkan filosofi positivis, dipakai guna mengkaji suatu populasi atau sampel, analisis data sifatnya kuantitatif atau statistik, serta tujuannya adalah untuk melakukan percobaan. Hipotesis yang telah dipilih sebelumnya.

\section{Jenis Penelitian}

Jenis penelitian yang dipakai adalah kuantitatif deskriptif. Menurut (Sugiyono, 2017), penelitian deskriptif memiliki tujuan mengetahui nilai variabel yang berdiri sendiri, baik itu satu atau lebih variabelnya.

\section{Sifat penelitian}

Penelitian ini sifatnya eksplanatori. (Indriartoro \& Supomo, 2014) menyatakan penelitian eksplanatori memiliki tujuan guna menjabarkan letak variabel yang menjadi fokus dan relasi variabel yang satu dengan lainnya.

\section{Populasi dan Sampel Populasi}

(Sugiyono, 2015) menyatakan populasi yaitu daerah penyamarataan yang termasuk objek serta subjek yang mempunyai karakteristik serta kualitas yang dipilih peneliti guna menjadi fokus serta dapat disimpulkan. Populasi dalam penelitian ini antara lain perusahaan manufaktur di industri barang konsumsi yang tercatat di BEI pada waktu observasi tahun 2016-2019.

\section{Sampel}

(Sugiyono, 2015) menyatakan sampel yaitu bagian kecil dari populasi. Metode yang digunakan adalah purposive sampling. Adapun syarat penentu sampel, yaitu :

\begin{tabular}{|l|l|l|}
\hline No & Kriteria & Jumlah \\
\hline 1 & $\begin{array}{l}\text { Perusahaan manufaktur sektor industri } \\
\text { barang konsumsi yang terdaftar di } \\
\text { BEI tahun 2016-2019 }\end{array}$ & 52 \\
\hline 2 & $\begin{array}{l}\text { Perusahaan yang menentukan laporan } \\
\text { keuangan tahun 2016-2019 }\end{array}$ & $(17)$ \\
\hline 3 & $\begin{array}{l}\text { Perusahaan yang memiliki laba yang } \\
\text { positif atau memperoleh laba tahun } \\
2016-2019\end{array}$ & $(8)$ \\
\hline 4 & $\begin{array}{l}\text { Perusahaan yang tidak mengalami ekuitas } \\
\text { negatif selama tahun 2016- } \\
2019\end{array}$ & (1) \\
\hline
\end{tabular}




\begin{tabular}{|l|l|l|}
\hline & $\begin{array}{l}\text { Jumlah perusahaan yang terpilih menjadi } \\
\text { sampel penelitian }\end{array}$ & 26 \\
\hline & $\begin{array}{l}\text { Total perusahaan yang menjadi sampel } \\
\text { penelitian (26 x 4 tahun) }\end{array}$ & 104 \\
\hline
\end{tabular}

(Data diolah Peneliti, 2020)

\section{Teknik Pengumpulan Data}

Teknik pengumpulan data didasarkan pada literatur, antara lain teknik yang sejalan dari buku, jurnal, artikel ilmiah, berita, serta sumber terpercaya lain yang berkaitan dengan topik penelitian.

\section{Jenis dan Sumber Data Penelitian}

Jenis penelitian ini sifatnya kuantitatif. (Sugiyono, 2015) menyatakan data kuantitatif artinya data berwujud angka atau yang diekstrapolasi. Dikatakan kuantitatif jika datanya cenderung dianalisis memakai metode statistik. Sumber data yang dipakai antara lain data sekunder. (Sugiyono, 2013) menyatakan data sekunder yaitu sumber data yang tidak didapatkan langsung oleh peneliti. Data sekunder didapatkan peneliti dari www.idx.co.id dengan wujud laporan keuangan publikasi perusahaan sampel.

\section{Definisi Operasional}

Jenis variabelnya yaitu variabel bebas serta variabel terikat, Definisi operasional variabel dirangkum pada tabel berikut ini :

\begin{tabular}{|l|l|l|}
\hline No & Variabel & Definisi Operasional \\
\hline 1. & $\begin{array}{l}\text { Kinerja } \\
\text { Keuangan } \\
\left(\mathrm{X}_{1}\right)\end{array}$ & $\begin{array}{l}\text { Menurut (Nisa \& Kurniasari, 2017), } \\
\text { kinerja keuangan adalah pencapaian } \\
\text { yang diperoleh perusahaan dan } \\
\text { tertuang pada laporan keuangan. }\end{array}$ \\
\hline 2. & $\begin{array}{l}\text { Struktur } \\
\text { Modal } \\
\left(\mathrm{X}_{2}\right)\end{array}$ & $\begin{array}{l}\text { Menurut (Maytariana \& Kertahadi, } \\
\text { 2013), menyatakan bahwa Debt to } \\
\text { Equity ratio digunakan untuk menilai } \\
\text { hutang dengan ekuitas. }\end{array}$ \\
\hline 3. & $\begin{array}{l}\text { Profitabilit } \\
\text { as (X) }\end{array}$ & $\begin{array}{l}\text { Menurut (Sartono, 2014), rasio } \\
\text { profitabilitas adalah rasio yang dapat } \\
\text { mengukur kemampuan perusahaan } \\
\text { mendapatkan laba, }\end{array}$ \\
\hline 4. & $\begin{array}{l}\text { Kebijakan } \\
\text { Hutang } \\
\left(\mathrm{X}_{4}\right)\end{array}$ & $\begin{array}{l}\text { Untuk mengukur tingkat kebijakan } \\
\text { hutang dapat menggunakan rasio } \\
\text { Debt to Total Asset Ratio. }\end{array}$ \\
\hline
\end{tabular}

\begin{tabular}{|l|l|l|}
\hline 5. & $\begin{array}{l}\text { Kebijakan } \\
\text { Dividen } \\
\left(\mathrm{X}_{5}\right)\end{array}$ & $\begin{array}{l}\text { dapat diukur dengan rasio Dividend } \\
\text { Payout Ratio (DPR), memberikan } \\
\text { gambaran oportunistik manajerial } \\
\text { yaitu dengan melihat seberapa besar } \\
\text { keuntungan yang dibagikan kepada } \\
\text { pemegang saham sebagai dividen. }\end{array}$ \\
\hline 6. & $\begin{array}{l}\text { Nilai } \\
\text { Perusahaa } \\
\mathrm{n}(\mathrm{Y})\end{array}$ & $\begin{array}{l}\text { Nilai perusahaan dapat diukur dengan } \\
\text { menggunakan rasio Price to Book } \\
\text { Value Ratio (PBV). Nilai perusahaan } \\
\text { publik ditentukan oleh pasar saham. }\end{array}$ \\
\hline
\end{tabular}

\begin{tabular}{|c|c|}
\hline Indikator & $\begin{array}{l}\text { Skala } \\
\text { Pengu } \\
\text { kuran }\end{array}$ \\
\hline Return On Asset $=\frac{\text { Laba Bersih }}{\text { Total Asset }}$ & Rasio \\
\hline Debt to Equity Ratio $=\frac{\text { Total Hutang }}{\text { Total Ekuitas }}$ & Rasio \\
\hline Net Profit Margin $=\frac{\text { Laba Bersih setelah Pajak }}{\text { Penjualan Bersih }} \times 100 \%$ & Rasio \\
\hline Debt to Asset Ratio $=\frac{\text { Total Liabilities }}{\text { Total Assets }}$ & Rasio \\
\hline Dividend Payout Ratio $=\frac{\text { Dividen per lembar saham }}{\text { Laba per lembar saham }}$ & Rasio \\
\hline Price to Book Value Ratio $=\frac{\text { Harga Pasar per Saham }}{\text { Nilai Buku per Saham }}$ & Rasio \\
\hline
\end{tabular}




\section{Uji Asumsi Klasik}

\section{Uji Normalitas}

(Ghozali, 2018) menyatakan terdapat dua metode untuk deteksi kenormalan distribusi residual dengan analisis grafik serta statistik.

\section{Uji Multikolonieritas}

Tujuan dari uji multikolonieritas yaitu untuk uji keterdapatan korelasi dari variabel independent pada model regresi. Menurut (Ghozali, 2018), Nilai cutoff yang biasanya digunakan guna menjadi bukti keterdapatkan multikolonieritas yaitu nilai toleransi $<0,10$ atau sama dengan $\mathrm{VIF}>0,10$.

\section{Uji Heteroskedastisitas}

(Ghozali, 2018) mengatakan bahwa dasar analisisnya yaitu apabila ada pola, titik yang berwujud pola teratur (gelombang, lebar serta menyempit), artinya mengalami heteroskedastisitas. Apabila pola jelas tidak ada, titik yang tersebar keatas dan berada dibawah 0 sumbu y maka tidak mengalami heteroskedastisitas.

\section{Uji Autokorelasi}

(Ghozali, 2016) menyatakan autokorelasi ada sebab terdapat peneltian yang terus menerus sepanjang waktu yang berhubungan satu dengar yang lainnya. Metode guna mengidentifikas keterdapatan autokorelasi yaitu uji Run Test.

\section{Model Analisa Data Penelitian Analisis Regresi Berganda}

Metode analisis yang digunakan adalah analisis regresi berganda untuk mengukur pengaruh dari variabel $\mathrm{X}$ terhadap variabel $\mathrm{Y}$. Dengan rumus sebagai berikut :

$$
\mathrm{Y}=\mathrm{a}+\mathrm{b} 1 \mathrm{X} 1+\mathrm{b} 2 \mathrm{X} 2+\mathrm{b} 3 \mathrm{X} 3+\mathrm{b} 4 \mathrm{X} 4+\mathrm{b} 5 \mathrm{X} 5+\mathrm{e}
$$

\section{a.}

Keterangan :

$$
\begin{array}{ll}
\mathrm{Y} & =\text { Nilai Perusahaan } \\
\mathrm{A} & =\text { Konstanta } \\
\mathrm{b} 1-\mathrm{b} 5 & =\text { Koefisien Regresi } \\
\mathrm{X} 1 & =\text { Kinerja Keuangan } \\
\mathrm{X} 2 & =\text { Struktur Modal } \\
\mathrm{X} 3 & =\text { Profitabilitas } \\
\mathrm{X} 4 & =\text { Kebijakan Hutang } \\
\mathrm{X} 5 & =\text { Kebijakan Dividen } \\
\mathrm{e} & =\text { Error (Estimasi Kesalahan) }
\end{array}
$$

\section{Uji Hipotesis Secara Simultan (Uji F)}

(Ghozali, 2018) menyatakan apabila nilai (sig.) uji $\mathrm{F}<0,05$ model yang dipakai layak serta mampu dipakai untuk analisis selanjutnya dan $\mathrm{d}$. berlaku sebaliknya.

\section{Uji Hipotesis Secara Parsial (Uji t)}

(Ghozali, 2018) menyatakan uji $t$ adalah untuk menampilkan besarnya dampak 1 variabel e. independen dengan individual saat menjabarkan variasi variabel dependen.

\section{HASIL DAN PEMBAHASAN}

\section{Gambaran Umum Bursa Efek Indonesia}

Pertumbuhan industri manufaktur Indonesia meningkat sangat tinggi. Ditinjau dari makin banyaknya jumlah yang tercatat tiap tahunnya. Perusahaan manufaktur adalah perusahaan yang tercatat di BEI, termasuk perusahaan yang go public, Perusahaan tersebut harus memiliki tingkat transparansi yang tinggi dan wajib membuat laporan keuangan yang sudah dievaluasi dengan tepat waktu. Perekonomian Indonesia sangat erat kaitannya dengan manufaktur, karena manufaktur merupakan sektor industri yang memberikan nilai tambah dan merupakan sektor terpenting dalam industri Indonesia.

\section{Deskripsi Data}

Hasil analisis deskripsi statistik, dapat disajikan Tabel 3.1 dibawah ini, yang menampilkan ciri sampel yang dipakai pada penelitian antara lain: total sampel $(\mathrm{N})$, nilai maksimum dan minimum, rata-rata sampel serta standar deviasi untuk setiap variabel

Tabel 3.1

Statistik Deskriptif
Descriptive Statistics

\begin{tabular}{|l|c|r|r|r|r|}
\hline & $\mathrm{N}$ & \multicolumn{1}{|c|}{ Minimum } & \multicolumn{1}{c|}{ Maximum } & \multicolumn{1}{c|}{ Mean } & \multicolumn{1}{c|}{ Std. Deviation } \\
\hline ROA & 92 &, 001 & 1,356 &, 13429 &, 171711 \\
DER & 92 &, 131 & 5,557 &, 84471 &, 873062 \\
NPM & 92 &, 002 & 1,213 &, 11263 &, 146247 \\
DAR & 92 &, 115 & 3,572 &, 41903 &, 388179 \\
DPR & 92 &, 000 & 11,515 &, 61266 & 1,293970 \\
PBV & 92 &, 011 & 229,353 & 9,69013 & 41,329129 \\
Valid N (listrise) & 92 & & & & \\
\hline
\end{tabular}

Berdasarkan tabel 3.1 menyatakan bahwa nilai min , nilai maks, nilai mean (rata-rata), dan standar deviasi dari variabel ROA (X1), DER (X2), NPM (X3), DAR (X4), dan DPR (X5) terhadap PBV Ratio (Y), yaitu:

Variabel ROA memiliki nilai min 0,001 di PT Kimia Farma Tbk tahun 2019, nilai maks 1,356 pada PT. Indofood CBP Sukses Makmur Tbk tahun 2018. Hasil nilai mean 0,13429 dengan standar deviasi 0,171711 .

b. Variabel DER memiliki nilai min 0,131 pada PT. Campina Ice Cream Industry Tbk tahun 2019, nilai maks 5,557 pada PT. Indofood CBP Sukses Makmur Tbk tahun 2017. Hasil nilai mean 0,84471 dengan standar deviasi 0,873062 .

c. Variabel NPM memiliki nilai min 0,002 di PT Kimia Farma Tbk Tahun 2019, nilai maks 1,213 pada PT. Indofood CBP Sukses Makmur Tbk tahun 2018. Hasil nilai mean 0,11263 dengan standar deviasi 0,146247.

Variabel DAR memiliki nilai min 0,115 pada PT. Campina Ice Cream Industry Tbk tahun 2019, nilai maks 3,572 pada PT. Indofood CBP Sukses Makmur Tbk tahun 2017. Hasil nilai mean 0,41903 dengan standar deviasi 0,388179.

Variabel DPR memiliki nilai min 0,000 di PT Multi Bintang Indonesia Tbk tahun 2017, nilai 
maks 11,515 pada PT. Campina Ice Cream Industry Tbk Tahun 2017. Hasil nilai mean 0,61266 dengan standar deviasi 1,293970.

f. Variabel PBV Ratio memiliki nilai min 0,011 pada PT. Gudang Garam Tbk tahun 2019, nilai maksimum 229,353 pada PT. Delta Djakarta Tbk tahun 2016. Hasil nilai mean 9,69013 dengan standar deviasi 41,329129.

\section{UJI ASUMSI KLASIK}

\section{Uji Normalitas}

Uji ini dipakai untuk uji kenormalan distribusi data residual berdistribusi. Peneliti memakai uji normalitas Kolmogorov-Smirnov pada penelitian ini. Dimana menjadi acuan penentu keputusan data mendekati atau berdistribusi normal yang memiliki syarat apabila nilai sig. > 0,05 data penelitian terdistribusi normal, dan jika nilai sig. $<0,05$, data penelitian terdistribusi tidak normal.

\section{Analisis Grafik}

\section{Histogram}

Analisis grafik guna untuk meninjau normalitas residual dengan meninjau grafik histogram dimana data observasi dan distribusi yang dekat dengan distribusi normal jika dibandingkan.

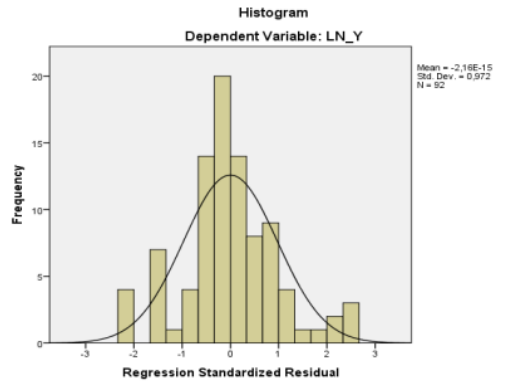

Gambar 3.1 Histogram

Berdasarkan gambar 3.1, kesimpulannya bahwa variabel tersebut berdistribusi normal. Dapat ditinjau dari data diatas dimana variabel tersebut terdistribusi tidak terlalu ke kiri ataupun ke kanan (kurva berwujud lonceng).

\section{Normal probability plot}

Dalam Pengujian ini, membandingkan distribusi kumulatif data asli dengan distribusi kumulatif distribusi normal. Distribusi normal menghasilkan satu garis lurus diagonal yang akan dilakukan perbandingan dengan plotting data

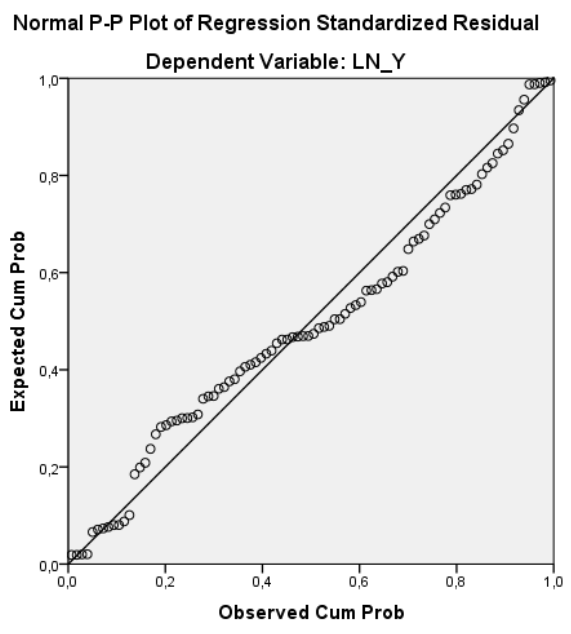

Gambar 3.2

Normal probability plot

Analisis statistik Kolmogorov Smirnov Test

Uji normalitas tujuannya guna meninjau kenormalan distribusi model regresi, variabel residual. Peneliti melalukan uji One Sample Kolmogorov Smirnov Test :

Tabel 3.2

One-Sample Kolmogorov-Smirnov Test

\begin{tabular}{|ll|r|}
\hline & & Unstandardized Residual \\
\hline $\mathrm{N}$ & Mean & 92 \\
Normal Parameters $\mathrm{a}, \mathrm{b}$ & $0 \mathrm{E}-7$ \\
& Std. Deviation & 2,06903022 \\
& Absolute &, 132 \\
Most Extreme Differences & Positive &, 128 \\
& Negative & -132 \\
& & 1,264 \\
Kolmogorov-Smirnov Z & &, 082 \\
Asymp. Sig. (2-tailed) & \\
\hline a. Test distribution is Normal. & \\
b. Calculated from data. &
\end{tabular}

Pada tabel 3.2 menyatakan variabel ROA (X1), DER (X2), NPM (X3), DAR (X4), dan DPR (X5) terhadap PBV Ratio (Y) terdistribusi normal dibuktikan dengan nilai signifikansi sebesar $0,082>0.05$.

\section{Uji Multikolinieritas}

Uji multikolinearitas dijalankan untuk uji keterdapatan korelasi variable bebas di model regresi. Model regresi harusnya tidak terjadi multikolinearitas. Untuk deteksi keterjadian multikolinearitas dapat ditinjau dari nilai VIF. Dapat dilihat hasil uji multikolinieritas terdapat di tabel 3.3 , yaitu :
Tabel 3.3

Hasil Uji Multikolinieritas 


\begin{tabular}{|c|c|c|c|}
\hline \multicolumn{4}{|c|}{ Coefficients ${ }^{2}$} \\
\hline \multirow{2}{*}{\multicolumn{2}{|c|}{ Model }} & \multicolumn{2}{|c|}{ Collinearity Statistics } \\
\hline & & Tolerance & VIF \\
\hline \multirow{6}{*}{1} & (Constant) & & \\
\hline & LN_X1 & 156 & 6,395 \\
\hline & LN_X2 & 095 & 10,480 \\
\hline & LN_X3 &, 157 & 6,383 \\
\hline & LN_X4 &, 096 & 10,441 \\
\hline & LN X5 &, 978 & 1,023 \\
\hline
\end{tabular}

Didasarkan tabel 3.3 dapat dilihat bahwa nilai tolerance variabel ROA (X1), DER (X2), NPM (X3), DAR (X4), dan DPR (X5) >0,1 kesimpulannya tidak mengalami multikolinearitas. Nilai VIF yang didapatkan untuk variabel ROA (X1), DER (X2), NPM (X3), DAR (X4), serta DPR $(\mathrm{X} 5)<10$ kesimpulannya tidak mengalami multikolinearitas.

\section{Uji Autokorelasi}

Uji autokorelasi dipakai agar diketahui keterdapatan korelasi anggota sampel yang urutannya didasarkan waktu yang menyebabkan model regresi tidak mampu dipakai menjadi penafsir variabel terikat (PBV Ratio) pada nilai variabel bebas ROA (X1), DER (X2), NPM (X3), DAR (X4), dan DPR (X5). Hasil autokorelasi pada Tabel 3.4 , yaitu:

Tabel 3.4

Hasil Uji Autokorelasi

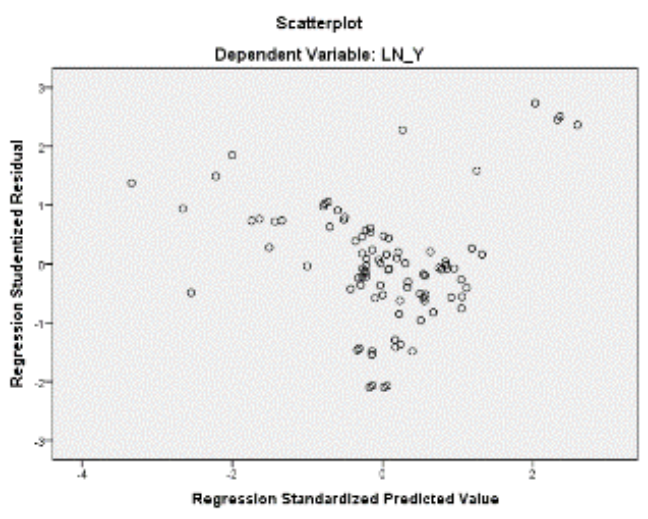

Gambar 3.3

Scatterplot

Dalam gambar 3.3 menyatakan data tidak membentuk dan tersebar pada suatu pola. Penyebaran data di atas serta di bawah garis 0 di sumbu $\mathrm{Y}$ artinya tidak mengalami heteroskedastisitas.

Terjadinya uji glejser jika variabel bebas tidak signifikan secara statistik berdampak pada variabel tidak bebas dengan sig. > 0,05. Namun, uji statistik mampu dijalankan dengan uji Glejser di tabel 3.5 :

Tabel 3.5

Hasil Uji Glejser

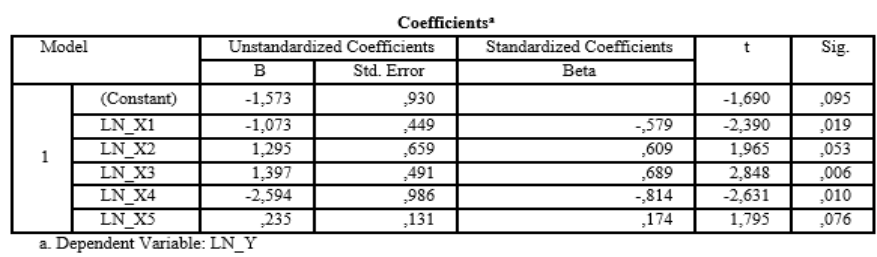

\begin{tabular}{|c|c|c|c|c|c|}
\hline \multicolumn{6}{|c|}{ Model Summary } \\
\hline Model & $\mathrm{R}$ & $\begin{array}{c}\mathrm{R} \\
\text { Square }\end{array}$ & Adjusted R Square & Std. Error of the Estimate & $\begin{array}{l}\text { Durbin- } \\
\text { Watsoon }\end{array}$ \\
\hline 1 &, $460^{4}$ &, 212 &, 166 & 1,70996 & 1,825 \\
\hline
\end{tabular}

Dalam tabel 3.4 menyatakan bahwa nilai Durbin Watson yaitu 1,825. Metode ukur uji autokorelasi yaitu du $<\mathrm{dw}<4$ - du. Pada penelitian ini nilai $\mathrm{dl}$ dan du menggunakan jumlah 5 variabel dan 92 sampel. Nilai $\mathrm{dl}=1.5482$ nilai $\mathrm{dw}=1,825$. Hasilnya adalah du $<$ dw $<4$ - du maka 1,7767 $<1,825<$ 2,2233 artinya tidak mengalami autokorelasi positif serta negatif pada penelitian ini.

\section{Uji Heteroskedastisitas}

Uji heteroskedastisitas dijalankan untuk uji keterjadian ketidaksamaan varian pada model regresi dari residual satu pengamatan ke yang lainnya. Deteksi heteroskedatisitas dijalankan dengan memakai grafik plot serta uji glejser. Pada grafik scatterplot, Heteroskedastisitas dideteksi dengan meninjau keterdapatan suatu pola di grafik scatterplot, dan sebaran data berada dekat 0 di sumbu Y.
Dari tabel 3.5 menunjukkan tidak adanya variabel bebas yang signifikansi terhadap variabel tidak bebas dengan nilai Logaritma Natural (Ln). Dapat dilihat dari PBV Ratio yang signifikansinya > tingkat kepercayaan 0,05. Kesimpulannya yaitu dalam penelitian ini ROA, DER, NPM, DAR, dan DPR signifikansinya diatas tingkat kepercayaan 0,05 tidak mengalami heteroskedastisitas.

\section{Hasil Analisis Data \\ Analisis Regresi Linear Berganda}

Analisis regresi linear berganda dipakai guna memprediksikan perubahan variabel terikat yang dijabarkan oleh dua ataupun lebih variabel bebas yang menjadi faktor prediktor yang diubah serta agar diketahui keterdapatan dampak variabel $\mathrm{X}$ pada variabel Y. Hasilnya ada pada tabel 3.6 : 
Tabel 3.6

Hasil Analisis Regresi Linier Berganda

\begin{tabular}{|c|c|c|c|c|c|c|}
\hline \multicolumn{7}{|c|}{ Coefficients $^{2}$} \\
\hline \multirow{2}{*}{\multicolumn{2}{|c|}{ Model }} & \multicolumn{2}{|c|}{ Unstandardized Coefficients } & \multirow{2}{*}{$\begin{array}{c}\text { Standardized Coefficients } \\
\text { Beta }\end{array}$} & \multirow[t]{2}{*}{ t } & \multirow[t]{2}{*}{ Sig. } \\
\hline & & $B$ & Std. Error & & & \\
\hline \multirow{6}{*}{1} & (Constant) & $-1,573$ & .930 & & $-1,690$ &, 095 \\
\hline & LN_X1 & $-1,073$ & ,449 &,- 579 & $-2,390$ &, 019 \\
\hline & LN_X2 & 1,295 & 659 & 609 & 1,965 &, 053 \\
\hline & LN_X3 & 1,397 & ,491 & ,689 & 2,848 &, 006 \\
\hline & LN_X4 & $-2,594$ & 986 &,- 814 & $-2,631$ &, 010 \\
\hline & LN_X5 & 235 &, 131 &, 174 & 1,795 &, 076 \\
\hline
\end{tabular}

Berdasarkan hasil analisis pada Tabel 3.6 persamaan regresi yang dipakai adalah sebagai berikut :

PBV $=1,573$ - 1,073 ROA - 1,295 DER + 1,397 NPM - 2,594 DAR - 0,235 DPR

Persamaan regresi tersebut berarti :

a. Nilai koefisien $\alpha-1,573$ artinya statistik saat seluruh variabel independen nilainya 0 maka nilai variabel dependen nilainya 1,573 .

b. Variabel ROA mempunyai koefisien regresi sebesar -1,073 yang menampilkan terdapat dampak negatif antara variabel ROA (X1) pada PBV Ratio sebesar 1,073 berarti ROA jika naik sebesar 1 satuan maka PBV Ratio akan menurun sebesar 1,073 dengan pemikiran variabel independen lain tetap.

c. Variabel DER mempunyai koefisien regresi sebesar 1,295 pada PBV Ratio sebesar 1,295 berarti DER jika naik sebesar 1 satuan maka PBV Ratio bertambah 1,295 dengan pemikiran variabel independen lain dijabarkan oleh variabel independen. Hasil Uji determinan $\left(\mathrm{R}^{2}\right)$ ada di tabel 3.7 :

\begin{tabular}{|l|c|c|c|c|}
\hline Model & R & R Square & Adjusted R Square & Std. Error of the Estimate \\
\hline 1 & & & & \\
\hline
\end{tabular}
a. Predictors: (Constant), LN_X5, LN_X3, LN_X4, LN_X1, LN_X2
b. Dependent Variable: LN_Y

Tabel 3.7

Koefisien Determinasi

Berdasarkan tabel 3.7 didapatkan nilai R Square (R2) koefisien determinasi sebesar 0,212 atau sama dengan $21,2 \%$. Artinya 21,2\% PBV Ratio mampu dijabarkan perubahan variabel independen serta $78,8 \%$ mendapatkan dampak terhadap variabel yang tidak diteliti.

\section{Pengujian Hipotesis Secara Simultan (Uji F)}

Uji F digunakan untuk pengukuran level keberartian relasi menyeluruh dari koefisien regresi dari variabel $\mathrm{X}$ pada variabel $\mathrm{Y}$ dengan memilih nilai uji $\mathrm{F}$ dengan tabel ANOVA serta tingkat signifikansi. Didasarkan hasil olah data memakai program SPSS, hasilnya sebagai berikut :

Tabel 3.8

Hasil Uji Statistik F

ANOVA*

\begin{tabular}{|c|c|c|c|c|c|c|}
\hline \multicolumn{2}{|c|}{ Model } & Sum of Squares & $\mathrm{df}$ & Mean Square & $F$ & Sig. \\
\hline \multirow{3}{*}{1} & Regression & 67,494 & 5 & 13,499 & 4,617 &, $001^{b}$ \\
\hline & Residual & 251,461 & 86 & 2,924 & & \\
\hline & Total & 318,954 & 91 & & & \\
\hline
\end{tabular}

tetap.

d. Variabel NPM mempunyai koefisien regresi sebesar 1,397 pada PBV Ratio sebesar 1,397 berarti NPM jika naik sebesar 1 satuan PBV Ratio meningkat 1,397 dengan pemikiran variabel independen lain tetap.

e. Variabel DAR mempunyai koefisien regresi sebesar -2,594 pada PBV Ratio sebesar 2,594 berarti DAR jika naik sebesar 1 satuan PBV Ratio turun -2,594 dengan pemikiran variabel independen lain tetap.

f. Variabel DPR memiliki koefisien regresi sebesar 0,235 pada PBV Ratio sebesar 0,235 berarti DPR apabila naik sebesar 1 satuan PBV Ratio meningkat sebesar 0,235 dengan pemikiran variabel independen lain tetap.

\section{Koefisien Determinasi $\left(\mathbf{R}^{2}\right)$}

Uji determinan $\left(\mathrm{R}^{2}\right)$ dilakukan agar diketahui besarnya varian dari variabel dependen mampu

b. Predictors: (Constant), LN_X5, LN_X3, LN_X4, LN_X1, LN_X2

Pada tabel 3.8, menunjukkan hasil dari Fhitung adalah 4,617 dengan nilai sig. 0,001 sedangkan Ftabel yaitu 1,662 dengan sig. 0,05 artinya Fhitung > Ftabel yaitu 4,617 > 1,662 serta sig. 0,001 <0,05, artinya $\mathrm{H0}$ diterima dan Ha ditolak. Variabel ROA, DER, NPM, DAR, dan DPR berdampak serta signifikan secara simultan pada PBV Ratio.

\section{Pengujian Hipotesis Secara Parsial (Uji t)}

Uji t dipakai sebagai uji apakah variabel $\mathrm{X}$ dengan berdiri sendiri memengaruhi variabel Y. Didasarkan hasil olah data memakai program SPSS, yaitu:

Tabel 3.9

Hasil Uji Statistik t

\begin{tabular}{|c|c|c|c|c|c|c|}
\hline \multirow{3}{*}{\multicolumn{2}{|c|}{ Model }} & \multicolumn{3}{|c|}{ Coefficients $^{2}$} & \multirow{3}{*}{$\mathrm{t}$} & \multirow{3}{*}{ Sig. } \\
\hline & & \multicolumn{2}{|c|}{ Unstandardized Coefficients } & \multirow{2}{*}{$\begin{array}{c}\text { Standardized Coefficients } \\
\text { Beta }\end{array}$} & & \\
\hline & & B & Std. Error & & & \\
\hline \multirow{6}{*}{1} & (Constant) & $-1,573$ & 930 & & $-1,690$ & .095 \\
\hline & $\overline{\text { LN_X1 }}$ & $-1,073$ &, 449 &,- 579 & $-2,390$ &, 019 \\
\hline & LN_X2 & 1,295 & .659 & .609 & 1,965 & 053 \\
\hline & LN X3 & 1,397 & 491 & ,689 & 2,848 & .006 \\
\hline & LN_X4 & $-2,594$ & 986 &,- 814 & $\begin{array}{l}2,631 \\
-2,631\end{array}$ & 0,010 \\
\hline & LN_X5 &, 235 &, 131 &, 174 & 1,795 & .076 \\
\hline
\end{tabular}


Hasil pengujian statistik secara parsial sebagai berikut :

a. Tabel 3.9 menyatakan variabel ROA memiliki nilai thitung -2,390 dengan sig. 0,019 , ttabel 1,662 dengan sig. 0,05 dapat disimpulkan thitung < ttabel yaitu $-2,390<$ 1,662 dan sig. $0,019<0,05$, artinya $\mathrm{H} 0$ ditolak dan $\mathrm{Ha}$ diterima dengan variabel ROA berdampak serta signifikan secara parsial pada PBV Ratio.

b. Tabel 3.9 menyatakan variabel DER memiliki nilai thitung 1,965 dengan sig. 0,053 , ttabel 1,662 dengan sig. 0,05 dapat disimpulkan thitung < ttabel yaitu 1,965 > 1,662 dan sig. $0,053>0,05$, artinya $\mathrm{H} 0$ diterima dan $\mathrm{Ha}$ ditolak dengan variabel DER tidak berdampak serta tidak signifikan secara parsial pada PBV Ratio.

c. Tabel 3.9 menyatakan variabel NPM mempunyai nilai thitung 2,848 dengan sig. 0,006 , ttabel 1,662 dengan sig. 0,05 dapat disimpulkan thitung < ttabel yaitu 2,848 > 1,662 dan sig. $0,006<0,05$, artinya $\mathrm{H0}$ ditolak dan Ha diterima dengan variable NPM berdampak serta signifikan secara parsial pada PBV Ratio.

d. Tabel 3.9 menyatakan variabel DAR mempunyai nilai thitung -2,631 dengan sig. 0,010 , ttabel 1,662 sig. 0,05 dapat disimpulkan thitung < ttabel yaitu $-2,631<$ 1,662 dan sig. $0,010<0,05$, artinya $\mathrm{H} 0$ ditolak dan Ha diterima dengan variabel DAR berdampak serta signifikan secara parsial pada PBV Ratio.

e. Tabel 3.9 menyatakan variabel DPR mempunyai nilai thitung 1,795 dengan sig. 0,076, ttabel 1,662 dengan sig. 0,05 dapat disimpulkan thitung < ttabel yaitu $1,795>$ 1,662 dan sig. 0,076>0,05, artinya $\mathrm{H} 0$ diterima dan Ha ditolak dengan variabel DPR tidak berdampak serta tidak signifikan secara parsial pada PBV Ratio.

\section{Pembahasan \\ Pengaruh Retrun of Asset Terhadap Price to Book Value Ratio \\ Hasil penelitian ini menyatakan ROA berdampak dan signifikan secara parsial pada PBV. \\ Sesuai dengan hasil dari penelitian (Nofrita, 2013) yang menyatakan bahwa ROA berdampak pada PBV. \\ Berdasarkan hasil penelitian ini makin besar nilai ROA, artinya makin efisien pemakaian aktiva perusahaan atau total aktiva dari keuntungan lebih}

tinggi, serta sebaliknya. Nilai ROA yang besar akan mengirim sinyal positif untuk investor bahwa perusahaan mendapatkan hasil keadaan yang untung yang jadi keinginan investor.

\section{Pengaruh Debt to Equity Ratio Terhadap Price to Book Value Rasio}

Hasil penelitian ini menyatakan DER tidak berdampak dan tidak signifikan secara parsial pada PBV Ratio.

Sesuai hasil Penelitian (Apsari et al., 2015) yang menyatakan bahwa DER tidak berdampak serta tidak signifikan parsial pada PBV.

Berdasarkan hasil penelitian ini DER tidak termasuk fokus tujuan investor dalam mengambil putusan pembelian saham pada suatu perusahaan karena para investor lebih meninjau masa depan perusahaan yang berdasarkan kerja keuangan perusahaan, yang mampu ditinjau investor dari tingkat keuntungan serta penjualan yang baik.

\section{Pengaruh Net Profit Margin Terhadap Price to Book Value Rasio}

Hasil penelitian ini menyatakan NPM berdampak serta signifikan parsial pada PBV Ratio.

Sesuai dengan hasil dari Penelitian (Itabillah, 2011) yang menyatakan bahwa NPM berdampak signifikan serta positif atas PBV Ratio.

Didasarkan hasil penelitian ini perusahaan perlu menjaga kestabilan keuangan dengan melakukan peningkatan laba pada penjualan produk, selain peningkatan laba perusahaan juga bisa melakukan pemeriksaan terhadap penggunaan aktiva yang ada pada perusahaan.

\section{Pengaruh Debt to Asset Ratio Terhadap Price to Book Value Ratio}

Hasil penelitian ini menyatakan DAR berdampak serta signifikan parsial pada PBV Ratio.

Sesuai hasil Penelitian (Batin \& Ismanto, 2020), dimana menyatakan bahwa DAR berpengaruh pada PBV Ratio.

Berdasarkan hasil penelitian ini menyatakan perusahaan belum mampu memiliki pendanaan dikarenakan hutang yang makin tinggi, maka makin susah untuk perusahaan mendapatkan pinjaman tambahan sebab perusahaan khawatir tidak dapat membayar hutang tersebut dengan asset yang dimiliki perusahaan.

\section{Pengaruh Dividen Payout Ratio Terhadap Price to Book Value Rasio}

Hasil penelitian ini menyatakan DPR tidak signifikan parsial dan tidak berdampak pada PBV Ratio. Sesuai dengan hasil dari Penelitian (Triyono, Raharjo \& Arifati, 2015) yang menyatakan bahwa DPR tidak berdampak pada PBV Ratio.Berdasarkan hasil penelitian ini menampilkan nilai perusahaan dipengaruhi oleh potensi dasar untuk menciptakan keuntungan serta risiko. Dapat dikatakan nilai 
perusahaan bergantung pada hasil dari aktiva, tidak pada cara pembagian hasil tersebut antara dividen serta keuntungan yang ditahay

\section{KESIMPULAN}

Dari hasil penelitian ini, dapat diambil kesimpulkan diperusahaan manufaktur bagian industri barang konsumsi yang tercatat di BEI tahun 2016-2019 bahwa :

ROA berpengaruh dan signifikan serta parsial pada PBV Ratio

DER tidak berdampak serta tidak signifikan secara parsial pada PBV Ratio.

NPM berpengaruh dan signifikan secara parsial pada PBV Ratio. PBV Ratio.

DAR berdampak serta signifikan parsial pada

DPR tidak berdampak serta tidak signifikan parsial pada PBV Ratio.

ROA, DER, NPM, DAR, serta DPR berdampak secara simultan pada PBV Ratio.

\section{Saran}

Berdasarkan hasil penelitian yang sudah penulis jabarkan, penulis mampu memberi saran, yaitu :

Untuk peneliti setelah ini sebaiknya meneliti memakai variabel lain yang mampu berdampak pada kebijakan dividen.

Untuk investor wajib memperhatikan faktor lain yang memberi dampak pada kebijakan dividen perusahaan.

Untuk Universitas Prima Indonesia, hasil penelitian ini mampu menjadi pedoman untuk penelitian selanjutnya dengan kajian yang lebih meluas

\section{REFERENSI}

Apsari, I. A., Dwiatmanto, \& Azizah, D. F. (2015). Pengaruh Return On Equity, Net Profit Margin, Debt to Equity Ratio, dan Long Term Debt to Equity Ratio Terhadap Price Bool Value. Jurnal Administrasi Bisnis (JAB), 27.

Batin, B. N., \& Ismanto, D. (2020). Pengaruh Current Ratio, Return On Equity Dan Debt To Asset Ratio Terhadap Price Book Value Perusahaan Advertising, Printing Dan Media Yang Terdaftar Di Bursa Efek Indonesia Periode 2014-2017. Jurnal Fokus Manajemen Bisnis, $9(2)$.

Brigham, E. F., \& Houston, J. F. (2011). Dasar-dasar manajemen Keuangan (1st ed.). Salemba Empat.

Dwi, C., \& Sudarwanto, T. (2014). Pengaruh Kualitas Layanan Dan Harga Terhadap Kepuasan Konsumen (Studi Pada Konsumen Coffee Corner Surabaya). Pendidikan, 2(2), 1-13.
Fahrizal, H. (2013). Pengaruh Return On Assets (ROA), Return On Equity (ROE) Dan Investment Opportunity Set (IOS) Terhadap Nilai Perusahaan (Vol. 53, Issue 8). Universitas Islam Negeri Syarif Hidayatullah.

Ghozali, I. (2016). Aplikasi Analisis Multivariate dengan Program IBM SPSS 23 (8th ed.). Badan Penerbit Universitas Diponegoro.

Ghozali, I. (2018). Aplikasi Analisis Multivariate Dengan Program IBM SPSS 25 (9th ed.). Universitas Diponegoro.

Hanafi, M. M., \& Halim, A. (2012). Analisis Laporan Keuangan, Edisi Keempat (4th ed.). UPP STIM YKPN.

Handayani, N. T. (2012). Pengaruh Financial Ratio Terhadap Pertumbuhan Laba Dengan Pengungkapan Corporate Social Responsibility Sebagai Variabel Pemoderasi. Management Analysis Journal, 1(2).

Indriartoro, N., \& Supomo, B. (2014). Metodologi Penelitian Untuk Akuntansi Dan Manajemen (1st ed.). BPFE.

Irham, F. (2011). Analisis Laporan Keuangan (10th ed.). Alfabeta.

Itabillah, E. A. (2011). Pengaruh CR, QR, NPM, ROA, EPS, ROE, DER dan PBV terhadap Harga Saham Perusahaan Property dan Real Estate yang Terdaftar di BEI. Jurnal Akuntansi.

Lestari, S., \& Paryanti, A. B. (2016). Pengaruh Profitabilitas dan Kebijakan Deviden Terhadap Nilai Perusahaan pada Perusahaan Perbankan yang Terdaftar di BEI Tahun 2006 - 2010. Jurnal CKI on SPOT, 9(1).

Mariani, D., \& Suryani. (2018). Pengaruh Kinerja Keuangan Terhadap Nilai Perusahaan dengan Kinerja Sosial dan Kinerja Lingkungan sebagai Variabel Moderator. Jurnal Akuntansi Dan Keuangan, 7(2).

Maytariana, D., \& Kertahadi, S. (2013). FaktorFaktor Fundamental Yang Mempengaruhi Struktur Modal Perusahaan. Jurnal Administrasi Bisnis, 2(2).

Mohanasundari, M., \& Vidhya, P. (2016). Dividend Policy and Its Impact on Firm Value: A Review of Theories and Empirical Evidence. Journal of Management Sciences and Technology, 3(3).

Murekefu, T. M., \& Ouma, O. P. (2012). The relationship between dividend payout and firm performance: a study of listed companies in kenya. European Scientific Journal, 8(9).

Nisa, F. N., \& Kurniasari, D. (2017). Pengaruh Islamic Corporate Social Responsibility Disclosure Terhadap Reputasi Dan Kinerja Keuangan Perusahaan. Jurnal Ilmu Manajemen Dan Akuntansi Terapan (JIMAT), 8(2).

Nofrita, R. (2013). Pengaruh Profitabilitas Terhadap Nilai Perusahaan Dengan Kebijakan Dividen Sebagai Variabel Intervening (Studi Empiris pada Perusahaan Manufaktur yang Terdaftar di BEI). Jurnal Ekonomi Universitas Negeri 
Padang.

Palupi, R. S., \& Hendiarto, S. (2018). Kebijakan Hutang, Profitabilitas dan Kebijakan Dividen Pada Nilai Perusahaan Properti \& Real Estate. Jurnal Ecodemica, 2(2).

Ramadhan, G., \& Marlina, W. T. (2016). Pengaruh Current Ratio, Debt To Equity Ratio, Dan Bopo Terhadap Capital Adequacy Ratio Dengan Return On Assets Sebagai Variabel Intervening Pada Perusahaan Perbankan Syariah Di Indonesia. Jembatan, 13(1).

Sartono, A. (2014). Manajemen Keuangan Teori dan Aplikasi (4th ed.). BPFE.

Sofyaningsih, S., \& Hardiningsih, P. (2011). Struktur Kepemilikan, Kebijakan Dividen, Kebijakan Hutang dan Nilai Perusahaan. Dinamika Keuangan Dan Perbankan, 3(1).

Sudana, I. M. (2011). Manajemen Keuangan Perusahaan Teori \& Praktik. Erlangga.

Sugiyono. (2013). Metode Penelitian Pendidikan Pendekatan Kuantitatif, Kualitatif, dan R\&D.
Alfabeta.

Sugiyono. (2015). Metode penelitian kombinasi (mixed methods). Alfabeta.

Sugiyono. (2017). Metode Penelitian Kuantitatif, Kualitatif dan $R \& D$. Alfabeta.

Triyono, Raharjo, K., \& Arifati, R. (2015). Pengaruh Kebijakan Deviden, Struktur Kepemilikan, Kebijakan Hutang, Profitabilitas, dan Ukuran Perusahaan Terhadap Nilai Perusahaan Pada Perusahaan Manufaktur di Bursa Efek Indonesia. Jurnal Akuntansi Dan Keuangan, $5(1)$.

Wijaya, W. (2010). Pengaruh Keputusan Investasi, Keputusan Pendanaan, dan Kebijakan Dividen Terhadap Nilai Perusahaan. Simposium Nasioanal Akuntansi XIII. 